\title{
Pengaruh Kualitas Pelayanan terhadap Kepuasan Masyarakat di Kantor SAMSAT Pati
}

\author{
Dzurrotin Nasihah \\ Prodi Magister Ekonomi Syariah, IAIN Kudus \\ *Email korespondensi: dzurrotinnasihah@gmail.com
}

\begin{abstract}
Public services are services provided by the government to the community. The services provided must be quality, directed and maximum. The SAMSAT office Pati is an agency that serves for the management of (1) Customs transfer of motor vehicle an average of 5,057 vehicles and 442 cars a month and (2) Vehicle tax totaling 8,959 units monthly and 4,289 for cars. The purpose of this study explains the empirical test results of the influence of SAMSAT service quality in Pati with indicators of attitude, speed, empathy, appearance and knowledge. The four standards are assessed by the community from the service experience obtained. This research uses a quantitative research approach. This type of research is field research. The method used is survey. Data analysis techniques used are the validity and reliability of the instrument, the classic assumption test, and the hypothesis test. Based on the calculation results $F$ count is greater than the F table (46.392> 3.30). The results of hypothesis testing indicate that there is a significant influence between good quality (reliability, responsiveness, assurance, empathy and physical evidence) on the satisfaction of motor vehicle taxpayers in SAMSAT Pati.
\end{abstract}

Keywords: Quality Service, Statisfaction Community, SAMSAT

Saran sitasi: Nasihah, D. (2020). Pengaruh Kualitas Pelayanan terhadap Kepuasan Masyarakat di Kantor SAMSAT Pati. Jurnal Akuntansi dan Pajak, 21 (1), 176-185. doi: http://dx.doi.org/10.29040/jap.v21i1.1154

DOI: http://dx.doi.org/10.29040/jap.v21i1.1154

\section{PENDAHULUAN}

Pelayanan publik merupakan suatu bentuk pelayanan yang diberikan oleh pemerintah kepada masyarakat. Pelaksanaan pelayanan publik dimaksudkan untuk memenuhi kebutuhan-kebutuhan yang sesuai dengan keinginan dan harapan masyarakat. Sesuai dengan UU No 25 Tahun 2009, pelayanan publik diartikan sebagai kegiatan dalam upaya memenuhi kebutuhan pelayanan yang sesuai dengan peraturan perundang-undangan bagi setiap warga negara atas barang dan jasa, maupun pelayanan administratif yang disediakan oleh penyelenggara pelayanan publik (Presiden Republik Indonesia, 2009).

Pelayanan yang diberikan kepada masyarakat harus senantiasa baik dan berkualitas mendekati harapan masyarakat karena baik buruknya pelayanan publik yang diberikan pemerintah kepada masyarakat sering dijadikan tolak ukur keberhasilan suatu instansi pemerintah (Wahjoe Pangoestoti \& Ramadhani Setiawan, 2016). Salah satu tuntutan masyarakat kepada pemerintah adalah peningkatan kualitas pelayanan publik, maka disusun suatu aturan dan ketentuan dalam pelayanan kepada masyarakat. Hal tersebut dimaksudkan agar pelayanan yang diberikan agar lebih terarah dan maksimal (Imanuddin \& Hidayat, 2012).

Kantor Sistem Pelayanan Satu Atap (Samsat) Kota Pati merupakan salah satu instansi pemerintah yang memberikan pelayanan kepada publik/ masyarakat yang berkaitan dengan pembayaran pajak kendaraan bermotor. Samsat Kota Pati memberikan pelayanan kepada masyarakat untuk pengurusan (1) Bea balik nama kendaraan bermotor (BBNKB). Pelayanan ini berupa pengurusan pembayaran pajak kendaraan bermotor baru roda dua maupun roda empat (mobil) atau pengurusan perubahan kepemilikan kendaraan bermotor karena terjadi proses jual beli. (2) Pajak kendaraan bermotor (PKB). Pelayanan ini berupa pengurusan perpanjangan pajak kendaraan bermotor roda dua maupun roda empat (mobil) rutin setahun sekali.

Kantor Samsat Kota Pati melayani rata-rata jumlah BBNKB untuk roda dua sebanyak 5.057 unit 
kendaraan perbulan. Sedangkan jumlah masyarakat yang mengurus PKB untuk motor sebanyak rata-rata 8.959 unit kendaraan perbulan. Untuk mobil rata-rata perbulan sebanyak 442 untuk pengurusan BBNKB dan 4.289 untuk pengurusan PKB. Mencermati data yang ada Kantor Samsat Kota Pati harus mampu memberikan pelayanan yang baik dan prima kepada masyarakat sehingga masyarakat mendapatkan kepuasan dalam pelayanan yang diberikan oleh Samsat Kota Pati.

Pelayanan menurut Kotler dan Keller merupakan setiap tindakan atas kegiatan yang dapat ditawarkan oleh suatu pihak kepada pihak lain yang pada dasarnya tidak berwujud dan tidak mengakibatkan kepemilikan apapun (Kotler \& Keller, 2009). Instansi pemerintah dalam hal ini Samsat Kota Pati harus memperhatikan kebutuhan konsumen, sebab pertumbuhan pelayanan akan sangat tergantung pada penilaian konsumen terhadap kinerja atau penampilan pelayanan yang ditawarkan oleh instansi pemerintah.

Pelayanan merupakan suatu kegiatan yang memiliki beberapa unsur ketakberwujudan yang berhubungan dengannya, yang melibatkan beberapa interaksi dengan konsumen atau dengan property dalam kepemilikannya, dan tidak menghasilkan transfer kepemilikan. Perubahan mungkin saja terjadi dan pelayanan bisa saja berhubungan atau bisa pula tidak berkaitan dengan produk fisik.

Kepuasan konsumen adalah respon atau reaksi terhadap ketidaksesuaian antara tingkat kepentingan sebelumnya dan kinerja aktual yang dirasakan setelah penggunaan atau pemakaian. Tujuan setiap pemasaran adalah menimbulkan kepuasan bagi konsumen. Jika konsumen puas terhadap barang tersebut atau terhadap pelayanan toko tersebut, konsumen akan melakukan pembelian ulang. Jika konsumen tidak puas, dia tidak akan melakukan pembelian ulang dan akan memberikan reaksi negatif serta menginformasikan reaksi negatif itu kepada keluarga, sahabat, sehingga pemasaran produk tersebut tidak mencapai sasaran. Hal ini dapat menimbulkan kegagalan bagi perusahaan (Herdiana, 2013).

Untuk memperjelas arah dan tujuan penelitian secara utuh, maka perlu diuraikan suatu konsep berpikir dalam penelitian ini sehingga peneliti dapat menguraikan tentang gambaran faktor yang mempengaruhi kepuasan wajib pajak dalam kaitannya dengan kualitas pelayanan.

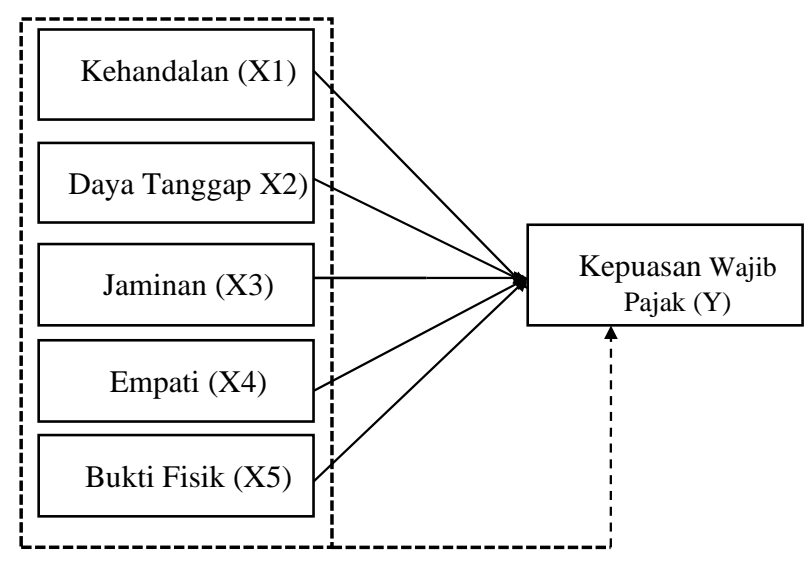

Gambar 1

Indiaktor Kepuasan Wajib Pajak

Namun kenyataanya, para wajib pajak masih merasakan pelayanan yang kurang maksimal, hal tersebut dilihat dari kritik dan saran yang diperoleh oleh SAMSAT Kota Pati sesuai dengan tabel 1.

\section{Tabel 1}

Kritik dan Saran Pelayanan di SAMSAT Pati

\begin{tabular}{lcc}
\hline \multirow{2}{*}{ Keluhan dan Saran } & \multicolumn{2}{c}{ Jenis Keluhan dan } \\
& 2017 & 2018 \\
\hline Prosedur dan persyaratan & 2 & 3 \\
Waktu pelayanan & 11 & 10 \\
Biaya pelayanan & 7 & 12 \\
Fasilitas pelayanan & 8 & 5 \\
Kesopanan dan & 5 & 7 \\
Keramahan & 18 & 20 \\
Biro jasa & 3 & 5 \\
Lain-lain & 54 & 62 \\
Jumlah &
\end{tabular}

Sumber : SAMSAT Kota Pati, 2018.

Data tersebut menunjukkan bahwa jumlah keluhan dan saran tahun 2017 dan tahun 2018 mengalamai kenaikan yaitu dari 54 keluhan dan saran menjadi 62 keluhan dan saran, walaupun jumlah kenaikannya tidak terlalu signifikan. Jika semua ketidaknyaman pelayanan di SAMSAT Kota Pati diadukan dan didata, mungkin saja jumlah keluhan dan saran akan jauh lebih banyak dibandingkan data yang tercantum di atas. Hal tersebut menunjukkan bahwa pelayanan yang dilakukan, masih belum dapat memuaskan wajib pajak yang melakukan pelayanan di SAMSAT Kota Pati.

Hasil penelitian terdahulu yang dilakukan oleh Edy Haryanto yang berjudul Kualitas Layanan, Fasilitas dan Harga Pengaruhnya terhadap Kepuasan 
Pengguna Jasa Layanan pada Kantor Samsat Manado menunjukkan bahwa kualitas layanan, fasilitas dan harga secara simultan berpengaruh positif dan signifikan terhadap kepuasan pengguna jasa layanan (Haryanto, 2013). Berbeda dengan penelitian yang dilakukan oleh Muhammad Amhas yang menyatakan bahwa secara langsung kualitas sumberdaya manusia tidak memiliki pengaruh terhadap kinerja, secara langsung kualitas layanan memiliki pengaruh terhadap kinerja, secara langsung kinerja pegawai memiliki pengaruh terhadap kepuasan pelanggan, sedangkan secara langsung kualitas sumberdaya manusia tidak memiliki pengaruh terhadap kepuasan pelanggan, secara langsung kualitas layanan memiliki pengaruh terhadap kepuasan pelanggan, dan secara langsung kinerja pegawai memiliki pengaruh terhadap kepuasan pelanggan (Amhas, 2018).

Penelitian ini berbeda dengan penelitianpenelitian sebelumnya. Tujuan penelitian ini yaitu menjelaskan hasil uji empiris pengaruh kualitas pelayanan Samsat Kota Pati terhadap kepuasan masyarakat. Hal itu dapat dinilai dari pelayanan yang diberikan oleh petugas yang berinteraksi langsung dengan masyarakat sesuai dengan standar pelayanan seperti sikap, kecepatan pelayanan, empati, penampilan dan pengetahuan tentang proses pelayanan. Keempat standar tersebut yang dinilai oleh masyarakat dan sebagai stimulus terciptanya kepuasan atau ketidakpuasan yang diperoleh dari pengalaman pelayanan yang diperolehnya.

\section{METODE PENELITIAN}

Penelitian ini menggunakan pendekatan penelitian kuantitatif yaitu penelitian yang menggunakan perhitungan statistik untuk mempermudah dalam pengolahan data yang didapat dari pengaruh kualitas pelayanan umum terhadap kepuasan wajib pajak kendaraan bermotor di SAMSAT Kabupaten Pati Tahun 2018. Jenis penelitian ini adalah jenis penelitian lapangan. Metode yang digunakan dalam penelitian ini adalah survey, dengan meneliti populasi yang relative luas dengan cara menentukan sampel yang mewakili dari populasi yang diteliti. Metode survey ini di lakukan dengan menyebarkan kuisioner/angket, dokumentasi. Penelitian ini menghubungkan dua variable saja yaitu kualitas pelayanan pajak kendaraan bermotor terhadap kepuasan masyarakat. Populasi dalam penelitian ini adalah wajib pajak kendaraan bermotor yang ada di wilayah Pati.
Pengumpulan data dalam penelitian ini dilakukan dengan membagikan kuesioner kepada responden. Sebelum dikirimkan kepada responden, dilakukan pretest atas kuesioner terlebih dahulu untuk meyakinkan bahwa kalimat yang ada dalam kuesioner mudah dipahami oleh responden. Setelah dilakukan pretest, kuesioner dikirimkan secara langsung ke Wajib Pajak Kendaraan Bermotor sebagai responden.

Angket kuesioner yang telah terkumpul telah dianalisis dan menghasilkan data. Teknik analisis data yang digunakan di penelitian ini yaitu uji validitas dan realibilitas instrument, uji asumsi klasik, dan uji hipotesis.

\section{HASIL DAN PEMBAHASAN}

\subsection{Hasil penelitian}

\section{Gambaran Umum Subyek Penelitian}

Pengambilan data dalam penelitian ini wajib pajak kendaraan bermotor yang ada di wilayah Pati. Penentuan jenis populasi ini didasarkan atas alasan bahwa yang akan diuji adalah kepuasan wajib pajak kendaraan bermotor di SAMSAT Kabupaten Pati. Deskripsi profil responden memberikan informasi demografi responden penelitian (jenis kelamin, usia, jenis pekerjaan, status pernikahan dan tingkat pendapatan). Profil responden dimaksudkan untuk menjelaskan latar belakang responden yang menjadi sampel dalam penelitian ini.

Dapat diketahui bahwa dari 106 responden yang menjadi sampel mayoritas responden berjenis kelamin laki-laki sebanyak 54 orang atau $51 \%$, sedangkan responden yang berjenis kelamin perempuan sebanyak 52 orang atau $49 \%$ dari keseluruhan jumlah sampel.

Demografi responden selanjutnya dilihat dari usia yaitu responden yang berusia 15-25 tahun yaitu sekitar 6 responden atau 6\%. Untuk usia 26-35 tahun sekitar 33 responden atau 31\%. Berusia 36-45 tahun sekitar 38 responden atau $36 \%$ dan berusia 46-55 tahun sekitar 29 responden atau $27 \%$.

Demografi responden selanjutnya dilihat dari jenis pekerjaan yaitu yang bekerja sebagai PNS yaitu sekitar 11 responden atau $10 \%$. Untuk pekerjaan swasta sekitar 17 responden atau $16 \%$. Jenis pekerjaan pelajar/mahasiswa sekitar 6 responden atau 6\%, bekerja sebagai dokter sekitar 5 responden atau $5 \%$. Untuk jenis pekerjaan ibu rumah tangga sekitar 37 responden atau 35\%. Dengan jumlah 24 responden atau $28 \%$ untuk jenis pekerjaan wirausaha. 
Demografi responden selanjutnya dilihat dari status pernikahan yaitu dengan status sudah menikah yaitu sekitar 74 responden atau $70 \%$ Untuk status pernikahan belum menikah sekitar 32 responden atau $30 \%$.

Demografi responden selanjutnya dilihat dari tingkat pendapatan yaitu yang mempunyai pendapatan $1.000 .000-2.500 .000$ juta yaitu sekitar 16 responden atau $15 \%$. Untuk pendapatan $2.500 .000-4.000 .000$ juta sekitar 38 responden atau $36 \%$. Tingkat pendapatan $>4.000 .000$ juta sekitar 41 responden atau 39\%. Dengan jumlah 11 responden atau 10\% untuk tingkat pendapatan lainnya.

\section{Statistik Deskriptif}

Fungsi analisis deskriptif adalah untuk memberikan gambaran umum tentang data yang telah diperoleh. Gambaran umum ini bisa menjadi acuan untuk melihat karakteristik data yang kita peroleh. Statistik deskriptif lebih berhubungan dengan pengumpulan dan peringkasan data, serta penyajian hasil peringkasan tersebut. Deskripsi kebutuhan aktualisasi diri, kebutuhan sosial dan kepuasan dapat dilihat dalam tabel berikut:

\section{a. Kehandalan (X1)}

Sebagian besar responden menyatakan bahwa kemampuan yang dapat diandalkan, akurat dan konsisten dalam mengerjakan jasa sesuai dengan yang diinginkan konsumen. Kehandalan ditunjukkan dengan beberapa indikator sebagai berikut memiliki standar pelayanan yang jelas; kecermatan petugas dalam pelayanan; konsisten kerja. Dengan nilai baik sebesar $69,8 \%$, jika dilihat menggunakan diagram batang akan terlihat sebagai berikut :

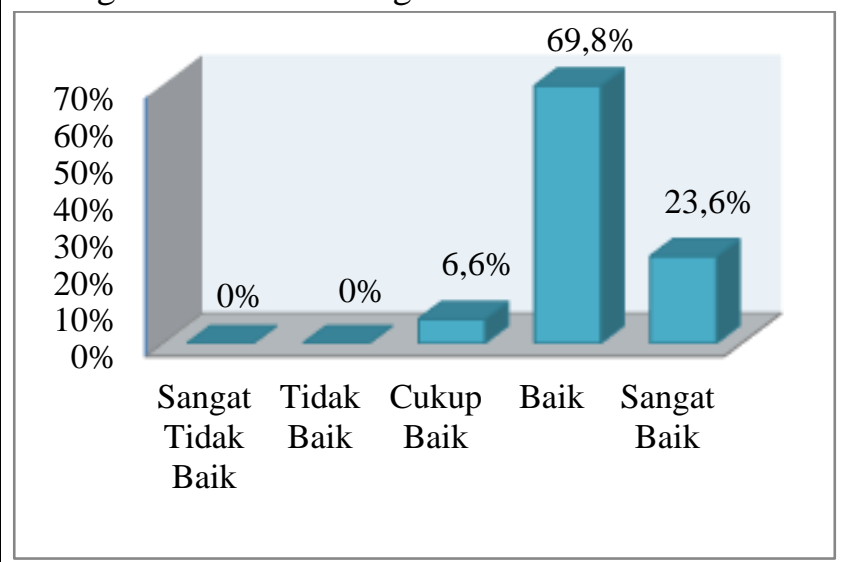

\section{Gambar 2}

Hasil Tanggapan Responden terhadap Kehandalan (X1)

\section{b. Daya Tanggap (X2)}

Sebagian besar responden menyatakan bahwa suatu kemauan untuk membantu dan memberikan pelayanan yang cepat (responsive) dan tepat kepada pelanggan, dengan penyampaian informasi yang jelas. Daya tanggap ditunjukkan dengan beberapa indikator sebagai berikut merespon setiap wajib pajak yang ingin mendapatkan pelayanan; petugas melakukan pelayanan dengan cepat dan tepat; petugas memiliki kemampuan dalam menangani permasalahan wajib pajak. Dengan nilai baik sebesar 56,6\%, jika dilihat menggunakan diagram batang akan terlihat sebagai berikut :

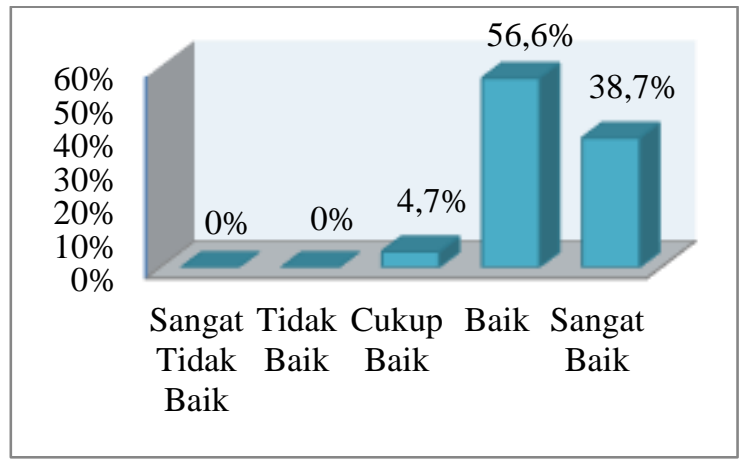

\section{Gambar 3}

\section{Hasil Tanggapan Responden terhadap Daya Tanggap (X2)}

\section{c. Jaminan (X3)}

Sebagian besar responden menyatakan bahwa pengetahuan dan kesopanan karyawan dan kemampuan mereka untuk menimbulkan kepercayaan dan keyakinan. Jaminan ditunjukkan dengan beberapa indikator sebagai berikut petugas memberikan jaminan tepat waktu dalam pelayanan; petugas memberikan perhatian pada wajib pajak; petugas memberikan jaminan kepastian biaya dalam pelayanan. Dengan nilai baik sebesar $70,8 \%$, jika dilihat menggunakan diagram batang akan terlihat sebagai berikut :

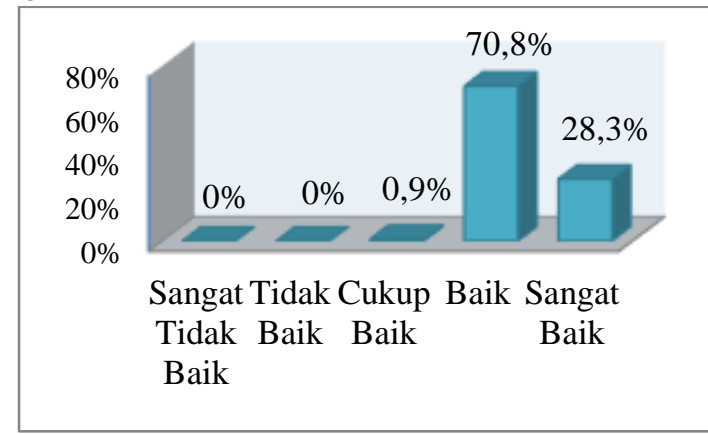

Gambar 4

Hasil Tanggapan Responden terhadap Jaminan (X3) 


\section{Jurnal Akuntansi dan Pajak, 21 (01), 2020, 180}

\section{d. Empati (X4)}

Sebagian besar responden menyatakan bahwa memberikan perhatian yang tulus dan bersifat individual atau pribadi yang diberikan kepada para pelanggan dengan berupaya memahami keinginan konsumen. Empati ditunjukkan dengan beberapa indikator sebagai berikut mendahulukan kepentingan pemohon/wajib pajak; petugas melayani dengan sikap ramah; petugas melayani dan menghargai setiap wajib pajak. Dengan nilai baik sebesar $83,0 \%$, jika dilihat menggunakan diagram batang akan terlihat sebagai berikut :

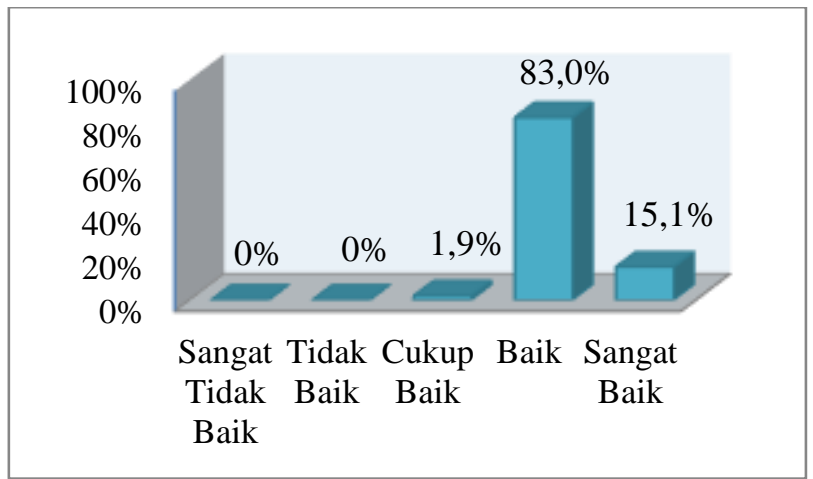

\section{Gambar 5}

\section{Hasil Tanggapan Responden terhadap Empati} (X4)

\section{e. Bukti Fisik (X5)}

Sebagian besar responden menyatakan bahwa penampilan dan kemampuan sarana dan prasarana fisik perusahaan dan keadaan lingkungan sekitarnya adalah bukti nyata dari pelayanan yang diberikan oleh pemberi jasa. Bukti fisik ditunjukkan dengan beberapa indikator sebagai berikut sarana fisik perkantoran (kenyamanan tempat untuk melakukan pelayanan); perlengkapan dan peralatan; kemudahan akses wajib pajak dalam permohonan pelayanan. Dengan nilai baik sebesar 74,5\%, jika dilihat menggunakan diagram batang akan terlihat sebagai berikut :

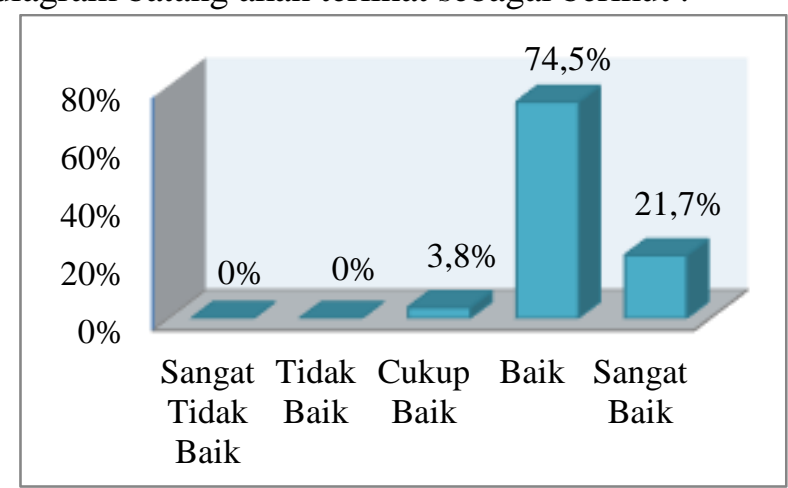

\footnotetext{
Gambar 6

Hasil Tanggapan Responden terhadap Bukti Fisik (X5)
}

\subsection{Pembahasan}

Berdasarkan penelitian dan analisis yang dilakukan, maka dapat diinterpretasikan sebagai berikut:

\section{Pengaruh Reliability terhadap Kepuasan}

Terdapat pengaruh yang signifikan antara kehandalan terhadap kepuasan wajib pajak kendaraan bermotor di SAMSAT Kabupaten Pati. Berdasarkan hasil perhitungan koefisien regresi sebesar 0,422 dan dengan nilai t hitung lebih besar dari pada t tabel $(4,458>1,98397)$, dan tingkat signifikansi $t$ sebesar 0,000 lebih kecil dari 0,05 . Nilai koefisien beta adalah positif, yang berarti bahwa berbagai item yang terdapat dalam kehandalan berpengaruh terhadap kepuasan wajib pajak kendaraan bermotor di SAMSAT Kabupaten Pati.

Hasil penelitian menunjukkan bahwa wajib pajak merasa pelayanan yang diberikan sesuai dengan yang dijanjikan. Wajib pajak merasa pengurusan validasi pajak kendaraan bermotor selesai tepat waktu. Petugas memberikan layanan pembayaran pajak secara sama untuk setiap orang. Petugas tidak membuat kesalahan dalam pencatatan dan pendaftaran pembayaran pajak kendaraan bermotor di SAMSAT. Petugas tidak membuat kesalahan dalam penghitungan pembayaran pajak kendaraan bermotor di SAMSAT. Pelaksanaan jam kerja SAMSAT dilakukan tepat waktu. Petugas SAMSAT mampu memberikan pelayanan pembayaran pajak dengan cepat. Petugas SAMSAT mampu memberikan pelayanan pembayaran pajak dengan tepat. Petugas SAMSAT melayani wajib pajak dengan sangat baik dan ramah. Saat mudah untuk memperoleh penjelasan tentang hal-hal yang berkaitan dengan pembayaran pajak kendaraan bermotor.

Di bidang pelayanan harus diingat selalu bahwa misi perusahaan adalah memberikan pelayanan terbaik agar tercapai kepuasan pelanggan. Kepuasan pelanggan dapat dilihat dari jumlah suatu barang atau jasa yang dikehendaki perusahaan pada suatu periode tertentu (Razy \& Ramadhansyah, 2019). Reliability, atau keandalan yaitu kemampuan perusahaan untuk memberikan pelayanan sesuai yang dijanjikan secara akurat dan terpercaya. Harus sesuai dengan harapan pelanggan berarti kinerja yang tepat waktu, pelayanan tanpa kesalahan, sikap simpatik dan dengan akurasi tinggi. Secara singkat dapat diartikan sebagai kemampuan untuk memberikan layanan yang dijanjikan secara akurat, tepat waktu, dan dapat dipercaya (Bursan, 2012). 


\section{Jurnal Akuntansi dan Pajak, 21 (01), 2020, 181}

Hasil penelitian ini sesuai dengan hasil penelitian Jarot Prianggono dan Dax E.S. Manupputy yang berjudul Pengaruh Kualitas Pelayanan terhadap Kepuasan Wajib Pajak dalam Penerbitan Surat Tanda Nomor Kendaraan di Samsat Balikpapan (Prianggono \& Manupputy, 2010) yang menunjukkan bahwa kehandalan berpengaruh terhadap kepuasan wajib pajak. Penelitian ini juga sejalan dengan penelitian yuwita (2018).

\section{Pengaruh Responsiveness terhadap Kepuasan}

Terdapat pengaruh yang signifikan antara daya tanggap terhadap kepuasan wajib pajak kendaraan bermotor di SAMSAT Kabupaten Pati. Berdasarkan hasil perhitungan koefisien regresi sebesar 0,137 dan dengan nilai $t$ hitung lebih besar dari pada t tabel $(2,325>1,98397)$, dan tingkat signifikansi t sebesar 0,006 lebih kecil dari 0,05 . Nilai koefisien beta adalah positif, yang berarti bahwa berbagai item yang terdapat dalam daya tanggap berpengaruh terhadap kepuasan wajib pajak kendaraan bermotor di SAMSAT Kabupaten Pati.

Hasil penelitian menunjukkan bahwa petugas SAMSAT bersedia menjawab pertanyaan mengenai pajak kendaraan bermotor. Petugas SAMSAT mampu menjelaskan prosedur pembayaran pajak kendaraan bermotor. Petugas SAMSAT selalu siap sedia membantu wajib pajak diminta maupun tidak. Petugas tanggap atas keluhan yang disampaikan oleh wajib pajak. Petugas SAMSAT dengan mudah memberikan solusi bagi wajib pajak yang tidak memiliki KTP asli BPKB motor. Petugas SAMSAT mampu memahami wajib pajak yang membawa syarat kurang lengkap. Petugas SAMSAT selalu sigap dalam menyelesaikan masalah yang dihadapi wajib pajak. Petugas SAMSAT mampu menyelesaikan setiap masalah dengan cepat. Petugas SAMSAT mampu menyelesaikan setiap masalah dengan tepat. Petugas SAMSAT mampu menjawab pertanyaan wajib pajak dengan jelas.

Kepuasan pelanggan dapat dilihat bila kualitas pelayanan yang telah diberikan dapat memenuhi keperluan pelanggan. Responsiveness, atau ketanggapan yaitu suatu kemauan untuk membantu dan memberikan pelayanan yang cepat (responsive) dan tepat kepada pelanggan, dengan penyampaian informasi yang jelas. Membiarkan konsumen menunggu tanpa alasan yang jelas menyebabkan persepsi yang negatif dalam kualitas pelayanan. Secara singkat dapat diartikan sebagai kemauan untuk membantu pelanggan dengan memberikan layanan yang baik dan cepat (Bursan, 2012).

Hasil penelitian ini sesuai dengan hasil penelitian Imanuddin dan Hidayat yang berjudul Analisis Kepuasan Pelayanan Pajak Kendaraan Bermotor Di SAMSAT Kota Semarang II (Imanuddin \& Hidayat, 2012). Temuan hasil penelitian menunjukkan bahwa daya tanggap berpengaruh terhadap kepuasan wajib pajak kendaraan bermotor.

\section{Pengaruh Assurance terhadap Kepuasan}

Terdapat pengaruh yang signifikan antara jaminan terhadap kepuasan wajib pajak kendaraan bermotor di SAMSAT Kabupaten Pati. Berdasarkan hasil perhitungan koefisien regresi sebesar 0,144 dan dengan nilai $\mathrm{t}$ hitung lebih besar dari pada t tabel $(3,221>1,98397)$, dan tingkat signifikansi t sebesar 0,025 lebih kecil dari 0,05 . Nilai koefisien beta adalah positif, yang berarti bahwa berbagai item yang terdapat dalam jaminan berpengaruh terhadap kepuasan wajib pajak kendaraan bermotor di SAMSAT Kabupaten Pati.

Hasil penelitian menunjukkan bahwa petugas SAMSAT menjamin tidak akan salah dalam pembayaran pajak. Petugas SAMSAT melayani wajib pajak sesuai dengan antrian. Petugas SAMSAT mampu menjamin tidak ada pungutan liar. Petugas SAMSAT menjamin tidak akan salah dalam perhitungan pajak kendaraan bermotor. Petugas SAMSAT memberikan jaminan kepastian biaya dalam pembayaran pajak kendaraan. Petugas SAMSAT mampu melakukan komunikasi yang efektif. Petugas SAMSAT menjaga kerahasiaan data wajib pajak. Petugas SAMSAT terampil dalam melayani wajib pajak. Informasi yang diberikan petugas SAMSAT dapat dipercaya. Petugas SAMSAT melayani wajib pajak sesuai dengan aturan.

Kepuasan pelanggan dapat dilihat bila kualitas pelayanan yang telah diberikan dapat memenuhi keperluan pelanggan. Ada beberapa hal yang menunjukkan pengaruh antara kualitas pelayanan dengan kepuasan pelanggan (Amhas, 2018). Assurance, atau jaminan dan kepastian yaitu pengetahuan, kesopan santunan, dan kemampuan para pegawai perusahaan untuk menumbuhkan rasa percaya pelanggan kepada perusahaan. Terdiri dari komponen: komunikasi (Communication), kredibilitas (Credibility), keamanan (Security), kompetensi (Competence), dan sopan santun (Courtesy). Secara singkat dapat diartikan sebagai 


\section{Jurnal Akuntansi dan Pajak, 21 (01), 2020, 182}

pengetahuan dan keramahtamahan personil dan kemampuan personil untuk dapat dipercaya dan diyakini (Bursan, 2012).

Hasil penelitian ini sesuai dengan hasil penelitian Harispiandi, dkk, yang berjudul Pengaruh Kualitas Pelayanan Pajak Kendaraan Bermotor terhadap Kepuasan Masyarakat di Kantor Samsat Kota Tanjungpinang Tahun 2015 (Razy \& Ramadhansyah, 2019). Kesimpulan dari hasil penelitian ini adalah persamaan regresi menunjukan bahwa jaminan berpengaruh terhadap kepuasan wajib pajak kendaraan bermotor.

\section{Pengaruh Empathy terhadap Kepuasan}

Terdapat pengaruh yang signifikan antara empati terhadap kepuasan wajib pajak kendaraan bermotor di SAMSAT Kabupaten Pati. Berdasarkan hasil perhitungan koefisien regresi sebesar 0,250 dan dengan nilai $\mathrm{t}$ hitung lebih besar dari pada $\mathrm{t}$ tabel $(2,233>1,98397)$, dan tingkat signifikansi $t$ sebesar 0,028 lebih kecil dari 0,05 . Nilai koefisien beta adalah positif, yang berarti bahwa berbagai item yang terdapat dalam empati berpengaruh terhadap kepuasan wajib pajak kendaraan bermotor di SAMSAT Kabupaten Pati.

Hasil penelitian menunjukkan bahwa petugas SAMSAT memberikan perhatian yang tulus kepada wajib pajak. Petugas SAMSAT memberikan waktu untuk menyelesaikan masalah yang berkaitan dengan pajak kendaraan bermotor. Petugas SAMSAT memberikan kemudahan dalam pelayanan. Petugas SAMSAT selalu bersikap simpatik dalam memberikan pelayanan. Petugas SAMSAT berusaha memberikan pelayanan yang terbaik. Petugas SAMSAT melayani wajib pajak dengan sikap ramah. Petugas SAMSAT memberikan perhatian yang ikhlas kepada wajib pajak. Petugas SAMSAT melayani wajib pajak dengan senyum. Petugas SAMSAT melayani wajib pajak dengan tidak marah-marah. Petugas SAMSAT melayani wajib pajak dengan sopan.

Bila kualitas pelayanan menunjukkan kepuasan yang tinggi, maka akan terjadi penekanan biaya pada titik yang terendah dan akan menjadikan pelanggan mengurangi biaya yang dikeluarkan. Faktor-faktor yang rendah menjadikan salah satu penentu kepuasan pelanggan. Empathy, yaitu memberikan perhatian yang tulus dan bersifat individual atau pribadi yang diberikan kepada pelanggan dengan berupaya memahami keinginan konsumen dimana suatu perusahaan diharapkan memiliki suatu pengertian dan pengetahuan tentang pelanggan, memahami kebutuhan pelanggan secara spesifik, serta memiliki waktu pengoperasian yang nyaman bagi pelanggan. Secara singkat dapat diartikan sebagai usaha untuk mengetahui dan mengerti kebutuhan pelanggan secara individual (Wahjoe Pangoestoti \& Ramadhani Setiawan, 2016).

Hasil penelitian ini sesuai dengan hasil penelitian Dewi yang berjudul Kualitas Pelayanan Samsat Keliling di Kantor Bersama Sistem Administrasi Manunggal Satu Atap (Samsat) Kota Madiun (Hartanti et al., 2020). Hasil penelitian menunjukkan bahwa empati berpengaruh terhadap kepuasan wajib pajak kendaraan bermotor.

\section{Pengaruh Tangibles terhadap Kepuasan}

Terdapat pengaruh yang signifikan antara bukti fisik terhadap kepuasan wajib pajak kendaraan bermotor di SAMSAT Kabupaten Pati. Berdasarkan hasil perhitungan koefisien regresi sebesar 0,503 dan dengan nilai t hitung lebih besar dari pada t tabel $(4,554>1,98397)$, dan tingkat signifikansi t sebesar 0,000 lebih kecil dari 0,05 . Nilai koefisien beta adalah positif, yang berarti bahwa berbagai item yang terdapat dalam bukti fisik berpengaruh terhadap kepuasan wajib pajak kendaraan bermotor di SAMSAT Kabupaten Pati.

Hasil penelitian menunjukkan bahwa gambar petunjuk atau alur pembayaran pajak kendaraan bermotor mudah dipahami. Lantai SAMSAT sangat bersih. Tersedia toilet yang bersih di SAMSAT. Pengeras suara yang digunakan untuk memanggil antrian sangat jelas. Tersedia tempat parkir yang luas dan memadai. Tersedia ruang tunggu yang nyaman. Tersedia brosur/leaflet pajak kendaraan bermotor. Kerapian penampilan petugas SAMSAT. Gedung atau kantor SAMSAT tempat pelayanan pembayaran pajak cukup layak. Letak atau lokasi SAMSAT yang strategis.

Untuk menciptakan kepuasan pelanggan adalah dengan menciptakan kualitas pelayanan yang tinggi dan upaya peningkatan kualitas pelayanan harus terus dilakukan menuju tingkat yang lebih tinggi lagi. Titik berat pelayanan jasa retail adalah penyediaan pelayanan yang baik dengan memperhatikan apa yang diinginkan oleh pelanggan. Apabila pelayanan yang diberikan tinggi, maka jumlah pelanggan akan meningkat (Razy \& Ramadhansyah, 2019). Tangibles, atau bukti fisik yaitu kemampuan suatu perusahaan 


\section{Jurnal Akuntansi dan Pajak, 21 (01), 2020, 183}

dalam menunjukkan eksistensinya pada pihak eksternal. Penampilan dan kemampuan sarana dan prasarana fisik perusahaan dan keadaan lingkungan sekitarnya adalah bukti nyata dari pelayanan yang diberikan oleh pemberi jasa. ini meliputi fasilitas fisik (Gedung, Gudang, dan lainnya), teknologi (peralatan dan perlengkapan yang dipergunakan), serta penampilan pegawainya. Secara singkat dapat diartikan sebagai penampilan fasilitas fisik, peralatan, personil, dan materi komunikasi(Bursan, 2012).

Hasil penelitian ini sesuai dengan hasil penelitian Jarot Prianggono dan Dax E.S. Manupputy yang berjudul Pengaruh Kualitas Pelayanan terhadap Kepuasan Wajib Pajak dalam Penerbitan Surat Tanda Nomor Kendaraan di Samsat Balikpapan (Prianggono \& Manupputy, 2010) yang menunjukkan bahwa bukti fisik berpengaruh terhadap kepuasan wajib pajak.

\section{Pengaruh Kehandalan, Daya Tanggap, Jaminan, Empati dan Bukti Fisik terhadap Kepuasan}

Terdapat pengaruh yang signifikan antara kehandalan, daya tanggap, jaminan, empati dan bukti fisik terhadap kepuasan wajib pajak kendaraan bermotor di SAMSAT Kabupaten Pati. Berdasarkan hasil perhitungan $F$ hitung lebih besar dari pada $F$ tabel (46,392>3,30), dan tingkat signifikansi t sebesar 0,000 lebih kecil dari 0,05. Kualitas pelayanan yang diberikan oleh pegawai SAMSAT Pati yang meliputi dimensi kehandalan, daya tanggap, jaminan, empati dan bukti fisik terbukti berpengaruh terhadap kepuasan wajib pajak kendaraan bermotor di SAMSAT Kabupaten Pati.

Besarnya korelasi atau hubungan antara variabel independen dengan variabel dependen dapat dilihat menggunakan nilai pada kolom R. Berdasarkan hasil penelitian dapat diketahui bahwa korelasi yang terjadi antara variabel bebas terhadap variabel terikat sebesar $r=0,836^{a}$, hal ini mengindikasikan bahwa variabel bebas kehandalan, daya tanggap, jaminan, empati dan bukti fisik, memiliki hubungan terhadap variabel terikat kepuasan (Y). Adapun hubungan yang terjadi adalah positif dan searah dengan tingkat hubungan yang tinggi.

Dari hasil analisis regresi linier berganda tersebut, diketahui bahwa koefisien determinasi yang dinotasikan dengan $R^{2}$ besarnya 0,699 . Ini berarti variabel kepuasan dapat dijelaskan oleh variabel kehandalan, daya tanggap, jaminan, empati dan bukti fisik, yang diturunkan dalam model sebesar 69,9\%, atau dengan kata lain sumbangan efektif (kontribusi) variabel independen terhadap variasi (perubahan) kepuasan (Y) sebesar 69,9\%. Variasi kepuasan (Y) bisa dijelaskan oleh variasi dari ketiga variabel independen, jadi sisanya sebesar $(100 \%-69,9 \%=$ $30,1 \%)$ kepuasan dijelaskan oleh variabel-variabel lain yang tidak dimasukkan dalam model penelitian ini, misalnya kepercayaan, kepemimpinan dan lainnya.

Kualitas pelayanan memiliki hubungan yang erat dengan kepuasan pelanggan. Kualitas memberikan suatu dorongan kepada konsumen untuk menjalin hubungan yang kuat dengan instansi/perusahaan. Dalam jangka panjang ikatan ini memungkinkan intansi/perusahaan untuk memahami dengan seksama harapan konsumen serta kebutuhannya. Dengan demikian instansi/perusahaan dapat meningkatkan kepuasan konsumen dan pada gilirannya kepuasan tersebut dapat menciptakan kesetiaan/loyalitas konsumen. Kualitas layanan dapat diwujudkan dengan memberikan layanan kepada konsumen dengan sebaik mungkin sesuai dengan apa yang menjadi harapan konsumen.

\section{KESIMPULAN}

Paradigma (pendekatan) penelitian yang mendasari dalam penelitian ini adalah positifistik kuantitatif yang ditujukan untuk menguji teori dalam hal ini adalah kualitas pelayanan. Secara operasioal, pengujian teori tersebut ditunjukkan dengan pengujian hipotesis yang diturunkan dari teori tersebutt.

Penelitian dilakukan di SAMSAT Pati, dengan subyek penelitian adalah wajib pajak kendaraan bermotor. Jumlah pengamatan adalah 106 sampel. Keenam hipotesis diuji secara empiris dalam penelitian ini, yaitu pengaruh kualitas pelayanan umum terhadap kepuasan wajib pajak kendaraan bermotor di SAMSAT Kabupaten Pati. Variabelvariabel tersebut diturunkan dari konsep kualitas pelayanan, yang bersumber dari grand theory.

Hasil pengujian hipotesis terhadap fakta lapangan yang dibantu dengan analisis statistik (regresi linier berganda) menunjukkan sebagaimana dalam kesimpulan sebagai berikut:

a. Terdapat pengaruh yang signifikan antara kehandalan terhadap kepuasan wajib pajak kendaraan bermotor di SAMSAT Kabupaten Pati. Berdasarkan hasil perhitungan koefisien regresi sebesar 0,422 . Nilai koefisien beta adalah positif, yang berarti bahwa berbagai item yang terdapat dalam kehandalan berpengaruh terhadap kepuasan 
wajib pajak kendaraan bermotor di SAMSAT Kabupaten Pati.

b. Terdapat pengaruh yang signifikan antara daya tanggap terhadap kepuasan wajib pajak kendaraan bermotor di SAMSAT Kabupaten Pati. Berdasarkan hasil perhitungan koefisien regresi sebesar 0,137. Nilai koefisien beta adalah positif, yang berarti bahwa berbagai item yang terdapat dalam daya tanggap berpengaruh terhadap kepuasan wajib pajak kendaraan bermotor di SAMSAT Kabupaten Pati.

c. Terdapat pengaruh yang signifikan antara jaminan terhadap kepuasan wajib pajak kendaraan bermotor di SAMSAT Kabupaten Pati. Berdasarkan hasil perhitungan koefisien regresi sebesar 0,144 . Nilai koefisien beta adalah positif, yang berarti bahwa berbagai item yang terdapat dalam jaminan berpengaruh terhadap kepuasan wajib pajak kendaraan bermotor di SAMSAT Kabupaten Pati.

d. Terdapat pengaruh yang signifikan antara empati terhadap kepuasan wajib pajak kendaraan bermotor di SAMSAT Kabupaten Pati. Berdasarkan hasil perhitungan koefisien regresi sebesar 0,250 . Nilai koefisien beta adalah positif, yang berarti bahwa berbagai item yang terdapat dalam empati berpengaruh terhadap kepuasan wajib pajak kendaraan bermotor di SAMSAT Kabupaten Pati.

e. Terdapat pengaruh yang signifikan antara bukti fisik terhadap kepuasan wajib pajak kendaraan bermotor di SAMSAT Kabupaten Pati. Berdasarkan hasil perhitungan koefisien regresi sebesar 0,503. Nilai koefisien beta adalah positif, yang berarti bahwa berbagai item yang terdapat dalam bukti fisik berpengaruh terhadap kepuasan wajib pajak kendaraan bermotor di SAMSAT Kabupaten Pati.

f. Terdapat pengaruh yang signifikan antara kehandalan, daya tanggap, jaminan, empati dan bukti fisik terhadap kepuasan wajib pajak kendaraan bermotor di SAMSAT Kabupaten Pati. Berdasarkan hasil perhitungan $\mathrm{F}$ hitung lebih besar dari pada $F$ tabel $(46,392>3,30)$. Kualitas pelayanan yang diberikan oleh pegawai SAMSAT Pati yang meliputi dimensi kehandalan, daya tanggap, jaminan, empati dan bukti fisik terbukti berpengaruh terhadap kepuasan wajib pajak kendaraan bermotor di SAMSAT Kabupaten Pati. g. Penelitian mendatang disarankan untuk mengembangkan berbagai faktor kontektual dalam memperhitungkan pengaruh variabel dalam kaitannya meningkatkan kualitas pelayanan.

\section{REFERENSI}

Amhas, M. (2018). Pengaruh Kualitas Sumber Daya Manusia, Kualitas Pelayanan Dan Kinerja Pegawai Terhadap Kepuasan Pelanggan Pada Kantor Sistem Administrasi Manunggal Satu Atap (Samsat) Makassar 01 Selatan. 3, 14.

Bursan, R. (2012). Analisis Pengaruh Kualitas Pelayanan Samsat Bandar Lampung Terhadap Kepuasan Wajib Pajak. 10(2), 10.

Hartanti, H., Alviani, R. K., \& Ratiyah, R. (2020). Pengaruh Samsat Keliling, Samsat Drive-Thru, E-Samsat Terhadap Penerimaan Pajak Kendaraan Bermotor Pada Kantor Samsat Jakarta Timur. Jurnal Online Insan Akuntan, 1(1), 125136.

Haryanto, E. (2013). Kualitas layanan, fasilitas dan harga pengaruhnya terhadap kepuasan pengguna jasa layanan pada kantor samsat manado. 11 .

Herdiana, N. (2013). Manajemen bisnis syariah dan kewirausahaan. Bandung: Pustaka Setia.

Imanuddin, A., \& Hidayat, Z. (2012). Analisis Kepuasan Pelayanan Pajak Kendaraan Bermotor Di SAMSAT Kota Semarang II. Journal of Public Policy and Management Review, 1(1), 21-30.

Kotler, P., \& Keller, K. L. (2009). Manajemen Pemasaran, Edisi 13. Jakarta: Erlangga, 14.

Ningsih, S. (2012). Pengaruh Service Quality terhadap Kepuasan Pelanggan Pada Lembaga Pendidikan Solocom di Surakarta. Benefit: Jurnal Manajemen dan Bisnis, 15(2), 125-134

Noor, L. K., \& Tanzil, F. F. (2020). The Effect Of Service Quality Education Academic And Facilities Student Satisfaction. International Journal of Economics, Business and Accounting Research (IJEBAR), 4(02).

Presiden Republik Indonesia. (2009). UndangUndang No 25 Tahun 2009.

Prianggono, J., \& Manupputy, D. E. (2010). Pengaruh kualitas pelayanan terhadap kepuasan wajib pajak dalam penerbitan surat tanda nomor kendaraan di Samsat Balikpapan. Makna: Jurnal Kajian Komunikasi, Bahasa, Dan Budaya, 1(2), $58-74$. 
Jurnal Akuntansi dan Pajak, 21 (01), 2020, 185

Razy, M. A., \& Ramadhansyah, F. A. (2019). Pengaruh Kualitas Pelayanan Pajak Kendaraan Bermotor Terhadap Kepuasan Masyarakat Labuhanbatu Utara Di Kantor Samsat Kampung Pajak. Kapital: Jurnal Ilmu Manajemen, 1(2).

Wahjoe Pangoestoti, \& Ramadhani Setiawan. (2016). Pengaruh Kualitas Pelayanan Pajak Kendaraan Bermotor Terhadap Kepuasan Masyarakat Di Kantor Samsat Kota Tanjungpinang Tahun 2015. Jurnal Umrah.
Pravasanti, Y. A., \& Tho'in, M. (2018). Meningkatkan Loyalitas Mahasiswa Melalui Service Performance. Relevance: Journal of Management and Business, 1(2). 